\title{
Tradisi Belis dalam Perkawinan Adat Suku Weelewo
}

\author{
Maria Lede', Zaini Bidaya², Zakaria Anshori ${ }^{3}$ \\ ${ }^{1}$ Pendidikan Pancasila dan Kewarganegaraan, Universitas Muhammadiyah Mataram, marialede10@gmail.com \\ ${ }^{2}$ Pendidikan Pancasila dan Kewarganegaraan, Universitas Muhammadiyah Mataram, zainibidaya@gmail.com \\ ${ }^{3}$ Pendidikan Pancasila dan Kewarganegaraan, Universitas Muhammadiyah Mataram, zakaria.anshori15@gmail.com
}

\section{INFO ARTIKEL}

\section{Riwayat Artikel:}

Diterima: 20 Agustus

2017

Disetujui: 30 September 2017

Kata Kunci:
tradisi
Belis
perkawinan
adat
suku
weelewo

\section{A. LATAR BELAKANG}

Indonesia merupakan Negara yang kaya berbagai ragamnya mulai dari suku, ras, agama, dan budaya/adat istiadat, yang masing-masing berbeda, dalam melangsungkan perkawinan. Setiap daerah di Indonesia ketika melangsungkan proses perkawinan, selalu dipenuhi dengan suasana yang sangat sakral dan kental. Hal ini disebabkan oleh kekuatan adat yang secara turun-temurun dipercayai oleh masyarakat, Indonesia sebagai suatu hal yang wajib di laksanakan oleh masyarakat [1]. Kearifan lokal merupakan elemen

\section{$---------$}

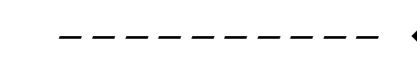

\begin{abstract}
Abstrak: Belis merupakan tradisi yang memiliki nilai-nilai luhur dan bentuk penghargaan terhadap perempuan. Permasalahan proses tradisi belis dalam perkawinan Adat Suku Weelewo menarik untuk dikaji secara ilmiah, khusunya mengapa masyarakat Desa Sangu Ate masih mempertahankan tradisi belis dalam perkawinan. Tujuan penelitian ini adalah untuk mendeskripsikan proses tradisi belis dalam perkawinan Adat Suku Weelewo pada masyarakat Desa Sangu Ate. Metode penelitian yang digunakan adalah kualitatif dengan pendekatan deskriptif. Metode pengumpulan data menggunakan observasi, wawancara, dan dokumentasi. Data kemuadian dianalisis melalui tiga tahap yakni reduksi data, penyajian data, dan penarikan kesimpulan sehingga tersusun rangkaian yang sistematis. Hasil penelitian menunjukkan bahwa tradisi belis dalam perkawinan Adat Suku Weelewo pada masyarakat Desa Sangu Ate merupakan prosesi perkwainan adat yang pembiayaanya sangat mahal, masyarakat menganggap hal ini sebagai bentuk kesungguhan dan kesanggupan dari pria yang ingin menikahi putri-putri Desa Sangu Ate. Tradisi belis keberlakuannya wajib bagi siapa saja yang ingin menikahi putri-putri Suku Weelewo. Hingga saat ini masyarakat Desa Sangu Ate masih mempertahankan tradisi belis dalam perkawinan adat Suku Weelewo,. Selain itu, menurut kepercayaan masyarakat Suku Weelewo menikah melalui prosesi tradisi belis mampu menciptakan keluarga yang kukuh hingga akhir hayat dalam ikatan keluarga yang kuat.
\end{abstract}

\begin{abstract}
Belis is a tradition that has noble values and forms of appreciation for women. The problem of the traditional Belis process in Customary marriage of the Weelewo Tribe is interesting to study scientifically, especially why the people of Sangu Ate Village still maintain the tradition of Belis in marriage. The purpose of this study was to describe the traditional process of Belis in the Weelewo Tribe Indigenous marriage in the community of Sangu Ate Village. The research method used is qualitative with a descriptive approach, Methods of collecting data using observation, interviews, and documentation. Next data to are analyzed through three stages, namely data reduction, data presentation, and concluding so that a systematic sequence arranged. The results showed that the tradition of Belis in the Weelewo Tribe Indigenous marriage to the people of Sangu Ate Village was a procession of traditional toys whose financing was costly, the community considered this as a form of sincerity and ability from men who wanted to marry the daughters of Sangu Ate Village. The tradition of Belis implementation is mandatory for anyone who wants to marry the daughters of the Weelewo Tribe. Until now, the people of Sangu Ate Village still maintain the tradition of Belis in the traditional marriage of the Weelewo Tribe. Also, according to the people's beliefs, the Weelewo tribe married through a regular procession of Belis able to create a healthy family until the end of life in a strong family bond.
\end{abstract}


perkawinan. Selain itu dipandang sebagai tradisi yang memiliki nilai-nilai leluhur, dan bentuk penghargaan terhadap perempuan, namun disatu sisi juga sebagai pengikat pertalian silaturami, kekeluargaan atau simbol untuk mempersatukan laki-laki, dan perempuan sebagai suami istri. "Belis" adalah salah satu utama yang wajib diberikan seorang laki-laki, kepada orang tua, atau keluarga seorang perempuan, yang telah menyerahkan seorang anak gadisnya kepada pihak orang tua, atau kelaurga lelaki [3]. Suku Wewewa merupakan salah satu suku yang berada di Pulau Sumba, mempunyai kekahasan juga dalam hal proses perkawinan. Belis (mas kawin) selalu menjadi kata kunci untuk membuka pintu pembicaraan kalau memang ada rencana untuk mengadakan sebuah perkawinan. Dan karena belis selalu menjadi kata kunci, maka tidak heran, kalau rasa cinta dalam banyak kasus pernikahan menjadi alpa[3].

Wilayah adat menjadi sesuatu yang tak tersentuh dalam sistem perkawinan adat Sumba Timur. Kalau pun ada beberapa model perkawinan yang mendukungnya, muncul atas pilihan dari pasangan calon pengantin, namun pada akhirnya kewajiban adat berupa belis adalah hal yang niscaya harus ditunaikan. Pada posisi ini individu tidak lagi ambil peranan melainkan komunitaslah yang berperan[4]. Beberapa pendapat di atas menguraikan berbagai nilai tentang perkwinan adat di Sumba. Tradisi belis setiap desa memiliki berbagai perbedaan terutama proses dan pelaksanaan maupun maupun dampak.

Berdasarkan hasil penelitian bahwa tradisi Belis dalam upacara perkawinan merupakan warisan budaya nenek moyang yang harus dipertahankan tetapi dalam pelaksanaan tradisi tersebut saat ini sudah berbeda dan memiliki pengaruh dan perubahan sosial, budaya, ekonomi masyarakat Kecamatan Wewewa Timur sangat besar serta berdampak negatif, dalam kehidupan masyarakat yang telah dibungkus oleh tradisi yang menekan keberadaan belis sebagai penunjang nilai ekonomi dalam menjalankan tradisi tersebut. Tradisi tersebut berfungsi sebagai sarana untuk mempererat hubungan kekerabatan antara Klan (Kabisu), di Kecamatan Wewewa Timur bukan sebagai suatu proses tawar-menawar secara pribadi antara yang dibelis dan yang membelis. Belis ini sangat berbeda dengan tata cara perkawinan adat yang di Indonesia lainnya, perbedaan itulan yang ingin diuraikan dalam artikel ini secara konkrit.

Proses meminang gadis dikalangan suku weeleo, Desa Sangu Ate, Kecamatan Wewewa Barat, sumba Barat Daya. Meski wilayah ini tidak memilihara Mamoli dan mata pencarian mereka kebanyakan petani dan nelayan, mamoli sudah memjadi mas kawin sejak ratusan tahun yang lalu. Dalam masyarakat Desa Sangu Ate, Kecamatan Wewewa Barat, Sumba Barat Daya, "Belis" selalu merupakan masalah rumit. Pembicaraan paling antara pihak keluaraga laki-laki, dan pihak keluarga perempuan, dan soal berapa banyak mamoli yang harus di berikan kepada pihak laki-laki, dan kepada pihak perempuan, sebagai maskawin [3]. Senada dengan hal ini dapat dilihat misalnya pada pola perkawinan piti maranggangu (ambil dalam pertemuan) yang tidak didahului dengan persetujuan dari si gadis, karena dilakukan melalui pengambilan gadis secara paksa atau juga dalam model perkawinan tama $\operatorname{rumbak}[4]$.

Jika calon istri berasal dari keluarga dengan status sosial tinggi, maka jumlah mamoli jahu lebih banyak, dan berapa berat mamoli, yang di tentukan, Kalau anak gadisnya berasal dari keluarga sederhana,maka jumlah dan ukuran mamoli, dan berapa beratnya, bisa dikompromikan, Jumlah mamoli untuk meminang seorang perempuang berkisar antara satu paket mamoli, atau lebih dari satu paket mamoli, biasanya berlaku dikalangan bangsawang atau orang terpandang, masyarakat pada umumnya satu paket Harga Mamoli bervariasi, yaitu Rp 25 juta, sampai 100 juta perpaket, tergantung berapa berat mamoli yang di tentukan oleh keluarga perempuan.

Hukum adat yang hidup bagi masyarakat Sumba memberikan titik terang dalam melaksanakan pernikahan secara adat, namun hukum adat yang ada belum berkembang secara utuh. Hukum adat sebagai institusi (warisan, hak adat, pegadaian, sewa, bagi hasil) masih relevan dengan pengembangan hukum nasional[5]. Sehingaa, adat Belis dapat menjadi inspirasi pengembangan hukum nasional dalam hal menemukan hukum dalam perkawinan adat bagi masyarakat Sumba.

Tujuan kajian dalam artikel ini adalah menjelaskan proses tradisi "Belis" pada masyarakat Desa Sangu Ate terhadap perkawinan,dan mengapa masyarakat Desa Sangu Ate masih mempertahankan Tradisi Belis tersebut.

\section{B. METODE PENELITIAN}

\section{Metode yang Digunakan}

Menggunakan metode kualitatif. dengan pendekatan deskriptif ini memjadikan penulis mudah dalam pengambilan data berupa tradisi Belis dalam perkawinan adat suku Weweleo, pada masyarakat Desa Sangu Ate, dan juga akan di ketahui bahwa benar adanya penelitian, Tradisi Belis dalam perkawinan di Desa Sangu Ate, Sumba Barat Daya. Menurut [6] dalam pandangan deskiptif berusaha memahami arti peristiwa dan kaitan-kaitannya terhadap orang yang berada dalam situasi-situasi tertentu. Fenomenologi adalah untuk menemukan pemikiran yang benar, seorang harus kemabali pada benda-bendnya [7]. Dari uraian di atas, maka dapat di simpulkan bahwa penelitian ini menggunakan metade penelitian kualitatif dengan pendekatan deskiptif yaitu: untuk mengali dan mentafsirkan peristiwa-peristiwa,fenomena-fenomena yang ada.

\section{Lokasi Penelitian}


Penelitian ini akan dilakukan Desa Sangu Ate Kecamatan Wewewa Barat Sumba Barat Daya yang terletak dipulau Sumba Barat Daya Nusa Tenggara Timur.

\section{Subjek Penelitian}

Subyek penelitian ini adalah masyarakat adat Desa Sangu Ate Kecamatan Wewewa Barat Sumba Barat Daya yang terletak dipulau Sumba Barat Daya, kepala adat, pemangku adat, tokoh adat, dan masyarakat Desa Sangu Ate.

\section{Teknik Pengumpulan Data}

Teknik yang digunakan dalam pengumpulan data yang relevan permasalahan penelitian adalahobservasi, wawancara dan dokumentasi.

1) Metode Observasi

Observasi adalah dasar semua ilmu pengatahuan. Para ilmuan hanya dapat bekerja berdasarkan data yaitu fakta mengenai dunia kenyataan yang diperoleh melalui observasi [8]. Tanpa partisipasi atau non partisipan yaitu: penelitian yang mengadakan pengamatandengan cara menyamar atau tidak di sadari kehadirannya itu sebagai pengamat. Akan tetapi dapat juga ia melakukan pengamatan itu secara terang-terangan [9].

Berdasarkan pendapat di atas, metode observasi yang yang digunakan dalam penelitian ini guna mengumpulkan data tentang tradisi belis dalam perkawinan Adat Suku Weelewo pada masyarakat Desa Sangu Ate.

2) Metode Wawancara

Wawancara adalah metode pengumpulan data, dengan cara menanyakan sesuatu kepada seseorang yang menjadi informasi atau responden, Caranya adalah dengan bercakap-cakap secara tatap muka [7].

Dari pendapat tersebut, maka wawancara digunakan dalam penelitian untuk memperoleh data tentang tradisi belis dalam perkawinan adat Suku Weelewo pada masyarakat Desa Sangu Ate dari kepala adat, pemangku adat, tokoh adat, dan masyarakat Desa Sangu Ate.

3) Metode Dokumentasi

Metode dokumentasi adalah mencari data mengenai hal-hal yang berbentuk,foto,gambar, buku, atau sejenis apa yang ada kaitan dengan penelitian [10].

Metode dokumentasi yang digunakan dalam penelitian untuk memperoleh data tentang tradisi belis dalam perkawinan adat Suku Weelewo pada masyarakat Desa Sangu Ate dari potret, dokumen, dan atau peneliti langsung yang merekan kejadian di lapangan dalam bentuk gambar dan dokumen lainnya.

\section{Teknik Analisis Data}

Setelah data yang diperoleh dan dikumpulkan maka dilakukan analisis data cara kualitatif. Di mana data yang diperoleh di lapangan direduksi, disajikan dan ditarik kesimpulan. Ada tiga (3) tahapan dalam menganalisis data kualitatif yaitu:

1) Meredukasi data,

Data ini merangkul, memilih hal-hal yang okok, menfokuskan pada hal-hal yang penting.Di cari tema dan pola. Dengan demikian data yang telah diredukasi akan memberikan gambaran yang lebih jelas dan mempermudah peneliti untuk melakukan pengumpulan data selanjutnya. redukasi data merupakan proses berfikir sensitif yang memerlukan kecerdasan dan serta pemahaman yang tinggi.

2) Penyajian Data(data display).

Langkah ini merupakan kesimpulan informasi tersusun yang memberikan pemahamanadanya penarikan dari kesimpulan. Setelah data di reduksi maka data tersebut di sajikan secara deskriptif,di mana hasil wawancara yang telah di lakukan di ubah bahasanya menjadi kalimat baku sehinggah mudah di mengerti dan di pahami.

\section{3) Verifikasi}

Langkah ketiga adalah menarik kesimpulan atau vertifikasi. Kesempulan merupakan temuan baru yang sebelumnya, perna ada temuan, dapat berupa deskriptif atau gambaran suatu obyek yang sebelumnya masihkurang atau belum jelas sehinggah telah di teliti menjadi jelas. Data display yang di kemukan,bilah telah di dukung Oleh data-data yang mantap, maka dapat di jadikan kesimpulan yang baik.

\section{HASIL DAN PEMBAHASAN}

\section{Konsep Perkawinan Menurut Adat Suku Weelewo}

Konsep perkawinan (dengan adanya klan penerima dan pemberi gadis) mengharuskan paling sedikit keterlibatan dua kabisu (suku) Misalnya suku A, B. Karena suku A adalah pemberi gadis untuk kabisu B maka kaum lelaki kabisu A tidak diperbolehkan menikahi wanita dari kabisu B, dengan kata lain tidak boleh terjadi salin bertukar peran diantara kabisu pemberi dan penerima gadis. Pernikahan dengan sesama anggota suku juga dilarang keras, bahkan dianggap sebagai perilaku tidak bagus yang bisa mendatangkan malapetaka, yang hanya bisa dipulihkan melalui upacara pemujaan.

Dalam adat perkawinan suku weelewo, belis melalui urusan pihak keluarga laki-laki, karena pihak perempuan juga harus menyediakan balasannya. Belis yang diberikan pihak laki-laki sering diasosiasikan dengan benda-benda maskulin seperti kerbau dan kuda, parang dan tombak (senjata perang), serta mamoli (perhiasan yang sering dipakai sebagai anting-anting). Sekilas mamoli tidak bersifat maskawin, tetapi perhiasan ini adalah penganti air susu ibu dan dalam perkawinan diberikan sebagai simbol pengganti wanita yang akan dibawa pergi. Sementara itu, balasan yang diberikan pihak perempuan diasosiasikan dengan benda-benda feminin seperti kambing (dipelihara kaum wanita) 
dan kain tenun (dibuat kaum wanita). Jumlah belis tergantung kesepakatan dan status sosial seseorang, terutama pengantin wanitanya. Untuk kalangan bangsawan biasanya sekitar 30 puluhan ekor, rakyat biasa antara 10 - 15 ekor, sedangkan belis golongan om dibayar olehkeluarga pria.

2. Proses tradisi "belis" dalam perkawinan Adat Suku Weelewo pada masyarakat Desa Sangu Ate terhadap Perkawinan.

Adat perkawinan Desa Sangu Ate merupakan tradisi turun temurun yang dilakukan hinggah sekarang, upacara ini merupakan upacara yang sakral yang hanya dilakukan oleh ketua adat. Adapun tahap upacara adat perkawinan Desa sangu ate.

1) Tahap perkenalan

Perkawinan yang dilakukan biasanya, melibatkan suku (kabisu). Jika ada dua suku yang masih merupakan suku bersaudara karena berasal dari satu leluhur maka diantara kabisu itu, tidak boleh terjadi kawin-mawin. Selain perkawinan antara anak paman dan anak tante, yang sangat dianjurkan tak dapat dihindari juga perkawinan yang terjadi atas kemauan dan atas dasar cinta, dari anak-anak sendiri. Sebelum memasuki tahapantahapan adat, diperlukan proses perkenalan agar dari kedua pihak keluarga mengetahui dengan jelas identitas ,atau status dan turunan -temurun dari bua wine maupun bua mane.

2) Tahap perkenalan adat (dengi winni pare, winni watara)

Pada tahap ini utusan pria berangkat dari keluarga pria, mereka bersiap dalam satu kesatuan keluarga yang disebut umba atau biasa disebut klen penerimanya wanita. Setelah sampai di rumah wanita, pembicaraan pinangan menggunakan bahasa adat yang disebut teda (sastra adat).

Pihak atau keluarga wanita akan memberikan siri pinang sebagai suguhan dan menanyakan maksud kedatangan umba,pada saat itu umba menyerahkan barang bawaan sambil meminta bibit padi (wini pare) dan bibit jagung (wini watara) sebagai tanda diterimanya pinangan.

3) Tahap ikat adat (kettege)

Setelah pinangan diterima tahap selanjutnya adalah ikat adat, sebagai lambang atau symbol kedua pihak keluarga bersatu yang haurs dipersiapkan adalah:a) Keluarga wanita, menyiapkan kain serta kambing; b) Keluarga pria, menyiapkan : hewan taguloka, artinya paman dan mamoli sebagai pengganti air susu ibu serta satu batang tombak dan rantai emas (lolo oma) sebagai symbol.

Saat tiba di rumah orang tua wanita, pria akan membawa tombak dan lolo oma yang akan diikat jadi satu, sebagai symbol kedua keluarga telah bersatu. Lalu rombongan pria menyerahkan hewan tagu loka dan mamoli. Sebagai balasannya keluarga wanita akan memberikan kain (motif sumba) serta satu kambing yang sudah dibunuh, dan satu lagi kambing yang masi hidup, sebagai tanda kesepakatan jumlah belis (welli).

4) Tahap ikat pindah (kete dikki)

Jika tahap ikat adat telah selesai, maka tahap selanjutnya adalah ikat pindah atau diresmikan secara adat wanita pindah ke suku pria. Adapun persiapa-persiapan yang harus dilakukan antara lain :

a. Keluarga wanita menyiapkan:

a) Kain dua puluh pasang (20) yang di bawa wanita ke rumahnya untuk dibagikan pada Mertua,dan ipar-iparnya.

b) Lemari yang telah di isi dengan berbagai perabot rumah tangga

c) Ayam mati dan ayam hidup untuk keluarga laki-laki

d) Ayam untuk keluarga perempuan sendiri

b. Keluarga laki-laki menyiapkan hewan sebanyak yang disepakati pada tahap ikatan adat.

Saat tiba waktu yang dijanjikan, oleh setiap jubir masing-masing keluarga mewakili untuk menanyakan kesipan keluarga. Jika semua sudah sesuai dengan rencana maka acarapun dimulai dengan menggunakan

Bahasa adat yang akan diakhiri dengan makan bersama dengan menggunakan peralatan makanan tradisional piring kayu (onga) dan piring anyaman lontar (kolaka) serta mangkok dari tempurung kelapa (koba) sesudah makan barulah anak wanita dibawah ke rumah suaminya. Bagi keluarga pria membawah pulang anak gadis merupakan kebanggaan tersendiri. Acara pemindahan ini akan diiringi bunyi gong, orang menari woleka, payawau dan pakalaka.

\section{TEMUAN DAN DISKUSI}

Proses adat perkawinan pada masyarakat Desa Sangu Ate merupakan salah satu tahap yang harus dilewati dalam upacara perkawinan dimana pada tahap ini, pihak Keluarga laki-laki menjemput mempelai perempuan. Karena pada hakikatnya, hukum perkawinan masyarakat Desa Sangu Ate bersifat Patrineal (Perempuan pindah ikut suami).

Dalam tradisi budaya masyarakat Desa Sangu Ate, Kecamatan Wewewa Barat Kabupaten Sumba Barat Daya, tata cara pelaksanaan upacara perkawinan adat suku weelewo adalah sebagai berikut:

1) Membuka/Memulai Pembicaraan

Sapaan awal dimaksudkan untuk membuka pembicaraan dan mengajak semua keluarga serta undangan yang hadir untuk mengambil bagian dalam pembicaraan acara pindah adat perkawinan "Padikkina Minne" pada masyarakat Desa sangu ate Kecamatan wewewa Barat Kabupaten Sumba Barat Daya Nusa Tenggara Timur”. Di samping itu sapaan awal juga dapat dibuka dengan Doa sesuai keyakinan dan atau permintaan keluarga.

Pembicara/moderator/perwakilan keluarga diawali dengan ramah dan pemberian sirih pinang serta kopi sebagai sambutan awal kekeluargaan untuk membina hubungan keakraban sekaligus meminta para jubir dan atau perwakilan kedua keluarga untuk mengambil tempat yang telah disiapkan oleh keluarga wanita. Untuk memulai pembicaraan orang tua laki-laki menyerahkan sebatang parang sebagai tanda menepati janji yang telah disepakati bersama pada saat kettekatongawerikawedo (masuk minta) dengan penuturan: 
"Ne loddo tomana kira dukkina ndadi hiddage Umbamu, neti kabatana lendakana kira bokkarana Ndadi”. Terjemahan: Hari ini tibalah waktu yang telah disepakati oleh besanmu dan lni sebatang parang sebagai tanda penepatan janji

Pembicaraan tersebut dimaksudkan untuk membuka pembicaraan awal serta menginformasikan kepada semua yang hadir yang turut serta dalam kegiatan adat tersebut. Selanjutnya akan di timpali oleh orang tua (pihak perempuan) sebagai tanda persetujuan atau membenarkan yang disampaikan oleh pihak orang tua laki-laki dengan memberikan selembar kain dan sarung. Adapun tuturannya sebagai berikut:

Neti ingngi, hinna takkadu paworo paduadama ba kira ba dadiwe ne loddo". Terjemahan: Ini kain, benar sekali kesepakatan kita bersama bahwa hari ini adalah waktu yang kita janjikan

Setelah orang tua perempuan menerima kehadiran dan penyampaian orang tua atau jubir dari pihak laki-laki serta penerimaan pemberian berupa parang, pembicaraan akan dilanjutkan oleh orang tua atau jubir dari keluarga laki-laki sebagai berikut;

"Neti kabatana, ba waiga ne loddo netti paworo paduadada panga'a nga'a paenu Wee ne loddo banna manowaradoga umbagu, kaku Lilli kaleku kaku Bengge wa kadanu hidda ranga a kabullu (paworo ba) monno na'i 'manu”. Terjemahan: Ini sebatang parang, kehadiran saya saat ini sesuai kesepakatan kita, kalau besan berkenan mengasihani kami, supaya hari ini juga kami mau membawa anak mantu kami dan hewan yang telah disepakti sejumlah 10 ekor hari ini juga sudah ada dan siap kami kasih serta ada kambing 1 ekor.

Adapun maksud tuturan tersebut untuk menjelaskan maksud dan kedatangan secara resmi dalam tikar adat pihak laki-laki ingin menjemput anak mantu sesuai dengan kesepakatan atau perjanjian pada saat Kette Katonga Weri Kawedo (Tahap Ikat). Selanjutnya, untuk menerima maksud dan tujuan kehadiran pihak keluarga laki-laki, maka orang tua perempuan atau orang yang diberi kuasa mensilahkan anak perempuannya untuk masuk ketempat yang telah disiapkan (Balitonga) dan si perempuan langsung memberi salam berupa berjabatan tangan dan berciumann kepada sang calon suami dan memberi kaleku (tempat sirih pinang) kepada Bapak dan Mama mantu serta semua keluarga yang hadir.

Kedua orang tua perempuan menghampiri orang tua laki-laki untuk memberi salam berupa pemberian kain dan sarung kepada Umba (orang tua laki-laki) (inggiumbaweeumba) selembar kain kepada Umba laki-laki dan selembar sarung kepada Umba perempuan sambil berjabatan tangan dan berciuman. Kedua orangtua laki-laki akan membalas memberi sebatang parang dan seekor hewan sebagai wujud rasa tanggung jawab dan penerimaan secara tulus kepada anak mantu/si perempuan (pawase). Adapun tuturannya;
"Nyado baba hinnatakkadu omu (papalawi lakawa minne monno wee Balena monno ngawu a li tilluna)".

Terjemahan Bebas; Benar yang disampaikan oleh besan, saya minta anak perempuan saya untuk mengambil tempat yang telah disiapkan dengan selempang kain dan salah satu dari keluarga perempuan membawa sejumlah kain yang disiapkan dan sudah diikat serta diletakkan di tengah-tengah ruang pertemuan.

2) Pemberian Tagu Loka (bagian Om)

Setelah Pawasse (Perempuan) berada di Balitonga (bale-bale yang telah disiapkan), Loka (Om) dari perempuan memberikan selembar kain dan selembar sarung dan mengajukan permintaan berupa seekor kerbau atau kuda. Permintaan Om (Loka) akan ditanggapi oleh orang tua lakki-laki. Apabila permintaan dari paman tidak dipenuhi maka urusan dikki akan tertunda dan atau tidak dapat dilanjutkan. Adapun tuturannya;

Nennati lokana (wolla wee wolla ingngi) iya

Ndara padengina Lokana. Terjemahan: Ini

dari Omnya (satu Sarung dan satu kain) dan satu ekor Kuda permintaan Om.

Selanjutnya orang tua laki-laki melalui Juru bicara memberikan sebatang parang dan satu ekor kuda untuk Omnya.Dalam tradisi adat perkawinan masyarakat desa Kabali Dana Kecamatan Wewewa Barat Om di pandang sebagai Pintu berkat dalam kelangsungan hidup bahtera rumah tangga.Karena itu permintaan dari omnya wajib diberikan pada saat acara pinda adat. Permintaan omnya akan dilangsungkan sebagai berikut;

"(na yawe gasu keto) iya ndara ba hinna ge lokana na tenawe Omu ka yani Iya Ndara”. Terjemahan Bebash. Ini sebatang parang dan satu ekor kuda untuk omnya.

Om (Loka) dalam budaya masyarakat desa Kabali Dana dipandang sebagai pintu berkat bagi kelangsungan hidup bahtera rumah tangga.Dalam Prosesi ini keluarga perempuan menanyakan dan menerima pemberian dari keluarga laki-laki sesuai permintaan berupa sebatang parang dan satu ekor kuda.

"Gei Ndara (kako etawa Ndara)".

Terjemahan: Di mana itu kuda saya mau lihat

Tradisi atau adat-istiadat tersebut sebagai bentuk permintaan Om yang harus dipenuhi dan apabila tidak dipenuhi, maka urusan Lilli Kaleku Bengge Kadanu akan ditunda dan atau tidak dapat dilanjutkan.

3) Pemberian Tagu Umma kalada (belis untuk rumah besar)

Orang yang tinggal dirumah besar akan memberikan selembar kain dan selembar sarung dan mengajukan permintaan seekor kerbau atau seekor kuda. Permintaan rumah besar (umma kalada)akan ditanggapi oleh orangtua laki-laki tentunya akan diwarnai dengan tawar nemawar sesuai kondisi ekonomi orang tua laki-laki. Adapun tuturannya:

"Kanyado na mababana lokana, neti tubana umma kalada padou kalaki lede wullu katowwa wolla wee wolla ingngi iya Ndara hinnage Umma Kalada”. Terjemahan; 
Baik kalau omnya sudah selesai bagian rumah besar sebagai tempat tali pusat dipotong dan rambut lahir dicukur.ada satu kain dan satu sarung sebagai permintaan satu ekor kuda untuk rumah besar. Apabila permintaan dari ummakalada (Rumah Besar) tidak dipenuhi maka urusan belis dalam perkawinanakan tertunda dan atau tidak dapat dilaksanakan.

4) Pemberian Imbalan Air Susu Ibu (Itta Kere Puaro Mata)

Pengorbanan ibu merupakan hal yang tak bisa dilupakan dalam kehidupan setiap orang. Dalam budaya adat perkawinan masyarakat desa sangu ate penghargaan terhadap seorang ibu merupakan salah satu hal terpenting sebagai bentuk balas budi. Adapun wujud dari Itta Kere Puaro Mata berupa satu buah mamoli emas atau dalam wujud Hewan Adapun tuturannya;

Nenti dommo wolla wee wolla ingngi

tubana innana a poddana pindala da

durage durana. Tuba itta kere puoro mata iya

Karambo Mane. Terjemhan: Ini lagi satu

Sarung dan satu Kain bagian ibunya.Yang selama ini merasakan sakit, Permintaan ibunya Satu Mamoli yang berupa Emas dan atau satu ekor Kerbau Jantan.

Apabila permintaan dari ibu tersebut tidak dipenuhi maka urusan dikkiakan tertunda dan atau tidak dapat dilaksanakan.

5) Urusan Belis

Setelah semua urusan Tagu Loka, Tagu Umma Kalada, dan Itta Kere Puaro Mata selesai, maka akan dilanjutkan dengan urusan belis (Wellina) dari orang tua perempuan[11]. Dalam tahap ini proses tawar menawar belis atau negosiasi berlangsung antara pihak perempuan dan pihak laki-laki tentunya melalui jubir masingmasing. Adapun tahapannya pada proses ini, sebagai berikut:

a. Pihak Perempuan

Pada tahap ini perempuan memberikan sejumlah kain dan sarung sambil meminta sejumlah hewan atau belis (kerbau dan kuda) kepada orang tua

laki- laki. Adapun tuturannya sebagai berikut: nennati karatuka takka monno na'i wawi mate monno wawi moripa ka nyado neti panga"a da nga'a paenu nda wee paworo puuna pakaddo lawena neti ranga oro teki a kabullu (paworo bada ) peina ole waidi?

Terjemahan Terikat:

nennati_karatukatakkamonno na’i
wawimatemonno

ini kain kusam tapi dengan itu babi mati dengan

wawi moripa kanyado netipanga"a da nga'apaenunda wee

hidup ini baik ini Makan makanan minuman ini air

paworopuunapakaddo lawena_netiranga oro tekia

kesepakatan pangkal sepakat Ujung ini hewan

bekas bicara yang

kabullu (paworo bada ) peinaole waidi?

sepuluh sepakat bagaimana kawan ada?

Terjemahan Bebas:
Ini kain dan sarung serta seekor kambing (mati) dan kambing (hidup) sebagai barang bawaan. Berkaitan dengan hewan kesepakatan dan atau perjanjian kita yang sepuluh ekor, apakah hari ini dibawa.

\section{b. Pihak laki-laki}

Orang tua laki-laki memberikan sebatang parang melalui juru bicara (ata panewe) sambil mengucapkan kata- kata berikut:

Neloddo bawaingga nda orokina bana tutuwe monno bana gennawe neti kupawee toddu kundo kupainggi paddo lako ndana toma toddu ndana dukkiwe tenda.Ku bole tuogu ku paluwe wekkigu, kukako kawodo katabaga netti barrami.Hinna wali kaiwe neti bawaingga ne loddo gaiwa ranga patalugu awaina pangindi monno nai manu patookowa manowara doga.

Terjemahan Terikat:

Neloddobawainggandaorokina bana tutuwe monnobanagennawe

Ini hari kami ada bukan karena sudah cukup dan sudah lengkap

Netikupaweetoddukundokupaingngi

pandolako

Itu bersarung atas lutut berkain bagi bahu

Ndanatamo toddundana dukkiwetenda

Tidak sampai di atas tidak sampai dibawa

Kuboletougu kupaluwewekkigu

Saya pukul diriku, saya pukul badanku,

Kukakokawodokatabaganettibarrami;

Saya jalan merayap tengkurap itu hari

Gaiwarangapatalugu awainapangindigu

Sekian hewan saya sanggup yang ada saya bawa

Monno naimanu pato'okowa umbabana manowaradoga

Dan itu ayam terserah besan dia ksihan sama saya

Terjemahan Bebas:

Kehadiran kami bukan karena cukup dan lengkapnya tapi kehadiran kami serba kekuranngan, dan dengan rendah hati kami mohon untuk dapat diterima apa adanya. Begitu pula kehadiran kami hannya membawa sekian hewan yang kami sanggup, semoga ayam itu dapat memberikan yang terbaik untuk kita semua.

Selanjutnya, dalam keadaan keterbatasan pihak keluarga laki-laki akan menyepakati dan memberikan kepastian memberikan hewan yang masih tersisah yang belum dilunasi pada saat Lilli Kaleku Bengge Kadanu. Adapun tuturannya:

Peiko Ge neti baku millandengo baku paingngi paddo lako baku pawee toddu kundo nemme ndou ka amidi umba gu wulla 6 poddu pakuada ka leduna umma katonga kadekewi hiddi ranga a limma takka hiddi a limma neti ku manairodi bana dadi ndou ka deke wi. 
Terjemahan Terikat :

Peiko Ge netibaku millandengo baku paingngipando lako

Bagaimana mana saya miskin saya berkain dobel bahu

bakupaweetodu kundonemmendou $k a$ amidi

saya bersarung atas lutut nanti tahun yang datang

umbagu wulla 6 poddupakuada kaleduna

besan saya bulan enam minggu

kedua menginjak

ummakatongakadekewihiddiranga

alimmatakkahiddia limma

rumah bale-bale injak itu hewan lima

tapii itu yang lima

neti kumanairodi bana dadindouka deke wi.

Ini saya berkebun kalau lahir tahun yang ambil

Terjemahan Bebas:

Keadaan kami serba kekurangan.Namun, kami telah berusaha dengan semaksimal mungkin. Sepulang sebentar dari tempat ini, ada lima ekor yang siap diambil. Namun yang lima ekor, mohon sekiranya Besan (orang tua perempuan) untuk memberi waktu sambil kami berkebun dan bertani agar hasilnya dapat kami gunakan untuk melunasi hutang adat kami.

Selanjutnya jika pihak dari perempuan menyetujui apa yang disampaikan oleh pihak laki-laki, maka pembicaraan akan diakhiri dengan tuturan sebagai berikut;

Kanyadoba Hinnako ge umbagu na tama ti'a na loga bukku neti a wolla ingngi tada na baku ndeibawe ne patekkina Umbagu.

Terjemahan Terikat;

KanyadobaHinnakoge umbagu natama ti’a nalogabukku

Baik nanti jadi dimana besan supaya masuk perut longgar leher

neti a wollaingngitada na baku

ndeibawene patekkinaUmbagu.

Ini yang satu kain tanda supaya aya terima ini pembicaraan besan

Terjemahan bebas;

Apa yang disampaikan oleh Besan kami terima. Oleh karena itu, ini satu kain dan satu sarung tanda pembicaraan serta janji yang kita utarakan bersama diikat secara adat.

Dengan disetujuinya pembicaraan tersebut, maka dengan sendirinya pembicaraan resmi antara Besan kedua belah pihak berakhir. Namun, pihak jubir yang diangkat pada pembicaraan tahap sebelumnya (Kette Katonga Weri Kawedo)[12]. Akan mempertanyakan keberadaan mereka, karena pembicaraan resmi sudah selasai.

Ada bentuk Pertukaran Sosial dalam Perkawinan Adat Sumba yaitu Belis yang dipertukarkan mempunyai pengaruh terhadap Kesejahteraan terhadap kedua belah pihak Keluarga diantaranya Kesejahteraan bagi pasangan yang baru menikah, keluarga laki - laki, dan Keluarga pihak perempuan. Saran dari peneliti dengan adanya Belis dalam perkawinan adat Sumba ini adalah Pemerintah bersama para tokoh - tokoh adat perlu melakukan pertemuan dan koordinasi dalam membahas kesulitan yang dialami, demi mendapat solusi yang berkaitan dengan jumlah Belis dan disisi lain masyarakat Sumba dapat mempertahankan kearifan lokal, adat dan budaya yang selama ini di jalankan[13].

Jadi Belis dapat dikatakan dengan mahar dalam perkawinan. Mahar merupakan simbol yang memiliki makna, dimana maknanya adalah berupa status sosial bagi kedudukan seorang perempuan dan keluarga besarnya. Semakin tinggi mahar maka semakin tinggi nilai dari status sosial perempuan tersebut[14]. Demikian pendapat lain mneyatakan bahwa nilai sosial pada perayaan tradisi perkawinan adat dipercaya akan mendatangkan suatu pengaruh yang kuat berkenaan dengan kehidupan sosial budaya[15]. Nilai - nilai keagamaan pada tradisi perkawinan adat adalah untuk lebih meningkatkan ibadah kepada Tuhan Yang Maha Esa dan pengucapan rasa syukur kepada Tuhan Yang Maha Esa karena telah diberi berkah, rahmat, serta pertolongan di masa sekarang dan dimasa yang akan datang.

\section{E. SIMPULAN DAN SARAN}

Proses adat perkawinan pada masyarakat Desa Sangu Ate, merupakan salah satu tahap yang harus dilewati dalam upacara perkawinan dimana pada tahap ini, pihak Keluarga laki-laki menjemput mempelai perempuan. Karena pada hakikatnya, hukum perkawinan masyarakat Desa Sangu Ate, bersifat Patrineal (Perempuan pindah ikut suami). Setelah semua urusan Tagu Loka, Tagu Umma Kalada, dan Itta Kere Puaro Mata selesai, maka akan dilanjutkan dengan urusan belis (Wellina) dari orang tua perempuan. Dalam tahap ini proses tawar menawar belis berlangsung antara pihak perempuan dan pihak laki-laki tentunya melalui jubir masing-masing.

Pengkajian masalah yang diangkat dalam penulisan ini masih terbatas oleh waktu dan kesempatan serta belum menyeluruh.Oleh karena itu, penulis mengharapkan adanya kajian lanjutan yang berkaitan dengan tulisan ini guna menambah wawasan dalam dunia linguistik kebudayaan.

\section{UCAPAN TERIMA KASIH}

Penulis mengucapkan terima kasih kepada editor yang senantiasa memberikan saran dan masukan kepada penulis sehingga artikel ilimiah ini selesai dengan baik.

\section{DAFTAR RUJUKAN}

[1] S. Soekanto, "Intisari Hukum Perikatan Adat," Jakarta Ghalia Indones., 1987.

[2] I. B. Brata, "Kearifan budaya lokal perekat identitas bangsa," J. Bakti Sar., vol. 5, no. 1, 2016.

[3] D. Kleden, "Belis dan Harga Seorang Perempuan Sumba (Perkawinan Adat Suku Wewewa, Sumba Barat Daya, NTT)," Stud. Budaya Nusant., vol. 1, no. 1, pp. 18-27, 2017.

[4] L. Muthmainnah and S. B. Trisakti, "Ruang 
Privat Individu Dalam Sistem Kawin Mawin Masyarakat Sumba Timur," J. Filsafat, vol. 20, no. 3, pp. 239-259, 2010.

[5] L. Abubakar, "Revitalisasi hukum adat sebagai sumber hukum dalam membangun sistem hukum indonesia," Din. Huk., vol. 13, no. 2, pp. 319-331, 2013.

[6] L. J. Moleong, "Metodologi Penelitian Kualitatif," Bandung PT Remaja Rosdakarya. Ed. Ke-13, vol. 111, 2001.

[7] B. A. S. Afifuddin and B. A. Saebani, "Metodologi penelitian kualitatif," Bandung CV Pustaka Setia, 2009.

[8] S. Nasution, Metode Research (Penelitian Ilmiah): usul tesis, desain penelitian, hipotesis, validitas, sampling, populasi, observasi, wawancara, angket. Bumi Aksara, 1995.

[9] T. Ryanto, "Ca-bau-kan'to Hit Theater Next Year," Jakarta Post, 2001.

[10] A. Suharsimi, "Prosedur Penelitian, Jakarta: PT," Rineka Cipta, p. 201:274, 2013.

[11] M. Widiyatmika, I. G. Suratha, and J. A. Frans, Adat istiadat dan upacara perkawinan suku Dawan, Sumba dan Lamaholot, Daerah Nusa Tenggara Timur. Biro Penelitian, Universitas Nusa Cendana, 1978.

[12] U. Rauta, I. Wauran, A. Siswanto, and D. H. Prananingrum, "Tiga Gerakan Moral Sebagai Hukum Adat Masyarakat Sumba Tengah," Refleks. Huk. J. Ilmu Huk., vol. 1, no. 2, pp. 213232, 2017.

[13] A. Hasan, "Pertukaran Sosial Dalam Perkawinan Adat Sumba Sebagai Upaya Pemenuhan Kesejahteraan Keluarga (Studi Pada Kampung Adat Tarung, Kecamatan Loli, Kelurahan Sobawawi, Sumba Barat, Nusa Tenggara Timur).” University of Muhammadiyah Malang, 2017.

[14] I. Ashari, "Makna Mahar Adat dan Status Sosial Perempuan dalam Perkawinan Adat Bugis di Desa Penengahan Kabupaten Lampung Selatan," 2016.

[15] F. Kamal, "Perkawinan adat jawa dalam kebudayaan indonesia," Khasanah Ilmu-Jurnal Pariwisata Dan Budaya, vol. 5, no. 2, 2014. 